\title{
The Importance of Innovations for Czech Business Companies
}

\author{
Radek Blahuš \\ Tomas Bata University, Faculty of Management and Economics, Czech Republic
}

\begin{abstract}
For European companies, as well as for companies from other developed countries, it is difficult to compete with low cost production from developing countries. One of their best competitive advantages in this fight can be innovations. Of course, due to the open nature of Czech economy, this is true for Czech business companies as well.

The main aim of this paper is to refer about quantitative questionnaire research among Czech business companies. This research focuses on the importance that Czech companies assign to innovations in relation to globalization of market in which they occur. It tries to find an answer to the question if Czech business companies assign more importance to innovations than companies in more local or more global markets.
\end{abstract}

Data was collected by e-mail quantitative questionnaire research during spring 2012 and was collected from 96 companies of all sizes from many branches. These companies were divided by globalization of markets where they operate by two factors - globalization of their customers and globalization of their competitors. They were asked about the importance they assign to outer innovation and inner innovation for their success on their market. For statistical evaluation analysis of variances and Sheffé method was used.

It was found there is nearly no difference between importance which companies assign to innovations, inner or outer, regardless the globalization of market they occur.

Keywords: Innovation, Inner and outer innovation, Globalization, Market changes.

\section{Introduction}

Porter says that competitive advantage can come either from cost leadership, or from differentiation. (Porter, 2004: 12) Cost leadership can be achieved by cutting costs, or by increasing efficiency. Differentiation can be achieved by improving the quality or by innovation of products (Roffe, 1999; Frankova 2011: 175).

Achieving these goals can be based on the size of the company and economies of scale as well as on the ownership of an unusual production factor. But the model which favours organizations that are able to use their knowledge, experience and technical abilities to produce new products, services or methods and how they produce or deliver them, is getting used much more often. (Tid, Bessant and Pavitt, 2007: 6) Instead of economies of scale, economies of choosing best range of products and services, or of readiness to meet market needs, are used very often. (Tomek and Vávrová, 2009: 64) Study cases show strong correlation between

Copyright (C) 2012 Radek Blahuš. This is an open access article distributed under the Creative Commons Attribution License unported 3.0, which permits unrestricted use, distribution, and reproduction in any medium, provided that original work is properly cited. Contact author: Radek Blahuš E-mail: blahus@fame.utb.cz 
market performance and new products. (Tid, Bessant and Pavitt, 2007: 6; Souder and Sherman, 1994; Tidd, 2000)

Drucker says that companies work in two time periods - today and in the future. But we have to remember that the future is being formed today. (Drucker, 1992; Barták, 2008: 144) In the past, it was a real competitive advantage to innovate products, to be creative and flexible. Nowadays, it is a necessity. Company has to be creative, innovative, flexible, cheap, fast and quality just to get on the market. (Kiernan, 1998: 43) If a company has an advantage, it can't fall asleep, but it has to continue building its advantage before the competitors can replicate it. Permanent innovation is the only way to retaining the advantage. (Kiernan, 1998: 43)

Although many companies understand this, they are not able to use innovations in practice. They have strategies, visions and many other documents aimed at permanent innovation. But innovation is hardly measurable, except external indices, such as patents. So motivation and reward for innovation ideas is also difficult to define. That leads to lower employee motivation to innovate anything in the company. (Adair, 2004: 167)

\section{Innovation}

Valenta defines innovation as every positive change in company - not only innovation of product or service. (Tomek and Vávrová, 2009: 64) Although it is quite difficult sometimes to recognize whether the change is positive or not and such a decision could take a long time, it is necessary to resolve this question. Cutting costs or increasing efficiency needs innovative ideas as well as the preparation of a new product or identifying a new market. Without new ideas in every part of their activities a company would become obsolete. It is true for products and services as well as for technologies, production, marketing, delivering of goods and so on. (Robins and Coulter, 2004: 59)

Schumpeter is more specific, and says that innovation includes:

- Production of a new product (or an existing one in higher quality)

- Introduction of a new manufacturing process

- Use of a new material or a semi-finished product or a source of it

- Obtaining a new market

- Changes in management and organization of production (Jáč, Ryvaldová and Žižka, 2005: 55)

Types of innovation listed by Schumpeter can be divided into two groups - inner innovations and outer innovations. (Robins and Coulter, 2004: 314) Inner innovations are innovationsdone inside the company and have almost no influence on customers introduction of a new manufacturing process and changes in management and organization of production. Production of a new product and occupation of a new market are outer innovations, because they influence customers. Use of a new material or a semifinished product can be inner innovations as well as outer innovations - depends on how much it influences the final product. We can use also Porter's view on competitive advantage - cost leadership and differentiation (Porter, 2004: 12). Then we can say that inner innovations primarily help reduce costs while outer innovations primarily help to differentiate products.

In the research part of this paper are used outer and inner innovations.

\section{Current Markets}

Current markets are changing - as well as they always have. For a company, each change means threat or potential for growth 
- so it's important to understand these changes and react to the flexibly. Primary current trends on markets are these:

\section{Fragmentation of Markets}

Marketing has changed from finding customers for our products to finding the best products for the customers. There are many markets or market niches, which are quite small. Companies that are not effective in some markets can focus on a market niche and try to differentiate special products or services for a small part of customers. (Košturiak and Chál', 2008: 5) In this case, new markets and also new branches are established. (Kiernan, 1998: 26) The process tends to one-to-one marketing manufacturing products according to individual customer requirements. (Kotler and Trias de Bes, 2005: 29)

\section{Disloyal Customers}

Loyal customers are economically beneficial. They buy more products, repeat purchases, are prepared to accept higher price, it's cheaper to serve him, because he requires lower sales promotion and if he is satisfied, he will tell his relatives.But nowadays customers are much more disloyal. Thanks to the internet, customers are able to buy goods from their home and find a new supplier very quickly and very easily. (Košturiak and Chál', 2008: 5)

\section{Innovation Cycles Fastens}

The period of time during which products remain on the market without any essential innovation is getting shorter. But also the period of time, that product needs to penetrate the market is shorter. Information shared by internet and demand for modern products helps a lot, as well as willingness of customers to try new brands. (Kotler and Trias de Bes, 2005: 24; Košturiak and Chál', 2008: 5)

\section{Copying is Very Quick and Nearly Perfect}

Nearly every product can be copied today. Copying of new, fashionable and successful products is common especially in developing countries, where respect for intellectual property is traditionally very low. This way, many innovative companies lose a lot of money. (Tid, Bessant and Pavitt, 2007: 7)

From these and many more changes (saturation of advertising, digital technology, increasing number of patents and trademarks (Kotler and Trias de Bes, 2005: 22-31), changes of life-style, hunger for emotions and adventure (Košturiak and Chál', 2008: 5-13)) we can make a conclusion, that competition is harder than ever before. (Kotler and Trias de Bes, 2005: 31)

So for companies it is very difficult to innovate. They innovate their products only for a small amount of disloyal customers. These products will become obsolete very quickly and will be copied very soon. And during all the time, a lot of competitors are trying to do the same.

But it is also very beneficial for a company if it is the first to use innovation or if it can define a whole new market. Pioneering helps build the company's reputation and its image as innovative and flexible company, first-time customers are very loyal to pioneering companies and often make repeat purchases and are willingness to pay much more for their product. (Thompson and Strickland 2001: 193)

Kiernan (1998: 79-80) lists more advantages. For example:

- Ability to set market standards

- Ability to be more flexible and respond to market opportunities

- Reduce business risk by placing news on the market very early after new opportunity is recognized 
- Ability to find and occupy the most effective and strategic distribution channels

- Confusing competitors by our constant and fast innovation, which pushes them to defensive position

But the position of first-mover also brings with it some disadvantages. It is very often much more costly to innovate then to imitate. Clever followers who not only copy but also improve the product can easily make more sophisticated products and win buyers away from the leader. (Thompson, 2001: 193)

Despite the high risk, innovativeness is very beneficial for many companies. Kotler and Trias de Bes (2005: 67-82) show us many examples of innovative companies, whose first-mover strategy was very successful and is nearly invincible (eg. Kinder surprise, Actimel, Barbie etc.).

\section{Situation in Czech Republic}

Czech economy is very open. Czech national bank states $75 \%$ share of exports in GDP in year 2010 (ČNB, 2012). For this reason globalization influences Czech business companies strongly. As can be seen, many of the market changes listed above are closely linked to globalization and to changes that come with globalization of markets.
It is an interesting question, if business companies in Czech Republic assign enough importance to innovations to be flexible and innovative enough to compete on such global markets. Another interesting question is if bigger companies with more global customers or more global competition assign higher importance to innovations for their success than companies operating in more local markets.

\section{Research Methodology}

The main aim of this research is to find out if local companies consider innovation less important than companies which operate on more global markets.

Data was collected by quantitative questionnaire research during spring 2012 from more than five hundred Czech business companies of all sizes from many branches. Questionnaires were sent out by e-mail. Questions were asked with predetermined range of possible responses and respondents could choose one or more answers according to the type of question - or specify their answers in text boxes. Return of questionnaires was quite low - so data was collected from only 96 companies.

Table 1 below shows relative and absolute frequency of companies divided by their size.

Table 1: Structure of Companies Divided by Its Size

\begin{tabular}{|l|l|l|}
\hline Company size (number of employees) & Absolute frequency & Relative frequency \\
\hline $1-10$ & 27 & $28,13 \%$ \\
\hline $11-50$ & 21 & $21,88 \%$ \\
\hline $51-250$ & 31 & $32,29 \%$ \\
\hline 251 or more & 17 & $17,71 \%$ \\
\hline Total & 96 & $100 \%$ \\
\hline
\end{tabular}

These companies were divided by globalization of markets where they operate by two factors - globalization of their customers and globalization of their competitors. In each of them three stages of globalization were used:
- Local market (Majority of customers / competitors or the most important customers / competitors come from the same region. Czech regions are comparable with British counties and are inhabited by half to one million people.) 
- National market (Majority of customers / competitors or the most important customers / competitors come from the same country. Czech Republic as a country is inhabited by 10 million people.)

- World market (Majority of customers / competitors or the most important customers / competitors come from all over the world.)

Differentiation by these two factors is important because many Czech companies operate only on local or national market but face real global world competition. For example, the favourite Czech drink company Kofola competes strongly with world producers Coca-cola and Pepsi, but operates especially in Czech Republic.

Companies were asked about the importance they assign to outer innovation and inner innovation for their success on their market. They were asked with predetermined fivepoint scale of importance where 5 meant essentially important and 1 meant almost or completely unimportant.
Four hypotheses were defined for this research.

Hypothesis $\mathbf{H}_{1}$ : Globality of customers has no significant influence on the importance that companies operating on the market assign to outer innovations.

Hypothesis $\mathbf{H}_{2}$ : Globality of customers has no significant influence on the importance that companies operating on the market assign to inner innovations.

Hypothesis $\mathbf{H}_{3}$ : Globality of competition has no significant influence on the importance that companies operating on the market assign to outer innovations.

Hypothesis $\mathbf{H}_{4}$ : Globality of competition has no significant influence on the importance that companies operating on the market assign to inner innovations.

For statistical verification of hypotheses analysis of variances was used. ANOVA table is used in this paper to show results of statistical calculations.

Table 2: ANOVA Table

\begin{tabular}{|l|l|l|l|c|}
\hline Source of variability & Sum of squares & Degrees of freedom & Mean square & Test criterion \\
\hline Within-group & & & $\frac{S_{A}}{r-1}$ & $\frac{\frac{S_{A}}{r-1}}{\frac{S_{E}}{n-r}}$ \\
\hline Between-groups & $\mathrm{S}_{\mathrm{A}}$ & $\mathrm{r}-1$ & $\frac{S_{E}}{n-r}$ & \\
\hline Total & $\mathrm{S}_{\mathrm{E}}$ & $\mathrm{n}-\mathrm{r}$ & & \\
\hline
\end{tabular}

$\mathrm{S}_{\mathrm{A}}$... Within-group variance

$\mathrm{S}_{\mathrm{E}}$... Between-group variance

$\mathrm{S}_{\mathrm{T}}$... Total variance

$r$... Number of factors

$\mathrm{n}$... Number of observations 
Globalization of market is used as a factor, importance of innovation is observed variable.

\section{Verification of Hypotheses}

\section{Verification of Hypothesis 1}

Hypothesis $\mathrm{H}_{\mathbf{1}}$ : Globality of customers has no significant influence on the importance that companies operating on the market assign to outer innovations.
Alternative Hypothesis $\mathbf{H}_{\mathrm{A1}}$ : Globality of customers has significant influence on the importance that companies operating on the market assign to outer innovations.

Table 3 shows responses about importance of outer innovations summarized and divided by globalization of customers. Results for ANOVA can be seen in table 4 .

Table 3: Importance of Outer Innovation Divided by Globalization of Customers

\begin{tabular}{|l|r|r|r|}
\hline Factor & Number of companies & Importance of innovation & \multicolumn{1}{l|}{ Arithmetic mean } \\
\hline Regional customers & 30 & 90 & 3,000 \\
\hline National customers & 36 & 141 & 3,917 \\
\hline Worldwide customers & 30 & 115 & 3,833 \\
\hline Total & 96 & 346 & 3,604 \\
\hline
\end{tabular}

Table 4: ANOVA Table for Hypothesis 1

\begin{tabular}{|l|r|r|r|c|}
\hline Source of variability & Sum of squares & \multicolumn{1}{|c|}{ Degrees of freedom } & Mean square & Test criterion \\
\hline Within-group & 16,04166667 & 2 & 8,020833333 & 4,635550567 \\
\hline Between-groups & 160,9167 & 93 & 1,730287097 & - \\
\hline Total & 176,9583 & 95 & - & - \\
\hline
\end{tabular}

For a level of significance 0,05 and the degrees of freedom $(2,93)$, the value of the critical region is 3,09433 .

As can be seen $4,63555>3,09433$.

Because the test criterion is higher than the critical region and doesn't fall within the critical region, hypothesis 1 is rejected.
Because the hypothesis is rejected, the alternative hypothesis is accepted - globality of customers has significant influence on the importance that companies operating on the market assign to outer innovations.

To find out which pairs of factors are significantly different, Sheffé method is used. Equality of expectations is rejected if:

$$
\left|\bar{x}_{i}-\bar{x}_{j}\right| \geq \sqrt{(I-1) s^{2} F_{1-\alpha}(I-1, n-1)\left(\frac{1}{n_{i}}-\frac{1}{n_{j}}\right)}
$$


7 Journal of Innovation \& Business Best Practice

Table 5: Schéffe Table for 3 Factors

\begin{tabular}{|l|c|l|}
\hline Compared pairs & Difference of expectations & Critical region \\
\hline 1,2 & $\left|\bar{x}_{1}-\bar{x}_{2}\right|$ & $\sqrt{(I-1) s^{2} F_{1-\alpha}(I-1, n-1)\left(\frac{1}{n_{1}}-\frac{1}{n_{2}}\right)}$ \\
\hline 2,3 & $\left|\bar{x}_{2}-\bar{x}_{3}\right|$ & $\sqrt{(I-1) s^{2} F_{1-\alpha}(I-1, n-1)\left(\frac{1}{n_{2}}-\frac{1}{n_{3}}\right)}$ \\
\hline 1,3 & $\left|\bar{x}_{1}-\bar{x}_{3}\right|$ & $\sqrt{(I-1) s^{2} F_{1-\alpha}(I-1, n-1)\left(\frac{1}{n_{1}}-\frac{1}{n_{3}}\right)}$ \\
\hline
\end{tabular}

Table 6: Schéffe Table for Hypothesis 1

\begin{tabular}{|l|r|r|}
\hline Compared pairs & Difference of expectations & \multicolumn{1}{|c|}{ Critical region } \\
\hline Companies with region / national customers & 0,9167 & 0,8089 \\
\hline Companies with national / worldwide customers & 0,0833 & 0,8089 \\
\hline Companies with region / worldwide customers & 0,8333 & 0,8449 \\
\hline
\end{tabular}

Calculation for level of significance 0,05 can be seen in table 6 .

As can be seen $0,9167>0,8089$.

So there is only one pair where difference of expectations is higher than critical region.

We can say that companies with local region customers consider outer innovation less important than companies with national customers.

There weren't any other statistically significant differences found between companies with more local or more global customers.

\section{Verification of Hypothesis 2}

Hypothesis $\mathrm{H}_{2}$ : Globality of customers has no significant influence on the importance that companies operating on the market assign to inner innovations.

Alternative Hypothesis $\mathbf{H}_{\underline{A 2}}$ : Globality of customers has significant influence on the importance that companies operating on the market assign to inner innovations.

Table 7 shows responses about importance of inner innovations summarized and divided by globalization of customers. Results for ANOVA can be seen in table 8.

Table 7: Importance of Inner Innovation Divided by Globalization of Customers

\begin{tabular}{|c|c|c|c|}
\hline Factor & Number of companies & Importance of innovation & Arithmetic mean \\
\hline Region customers & 30 & 105 & 3,500 \\
\hline National customers & 36 & 123 & 3,417 \\
\hline Worldwide customers & 30 & 95 & 3,167 \\
\hline Total & 96 & 323 & 3,365 \\
\hline
\end{tabular}


Table 8: ANOVA Table for Hypothesis 2

\begin{tabular}{|l|r|r|r|c|}
\hline Source of variability & \multicolumn{1}{|l|}{ Sum of squares } & Degrees of freedom & \multicolumn{1}{l|}{ Mean square } & Test criterion \\
\hline Within-group & 1,822917 & 2 & 0,911458 & 0,827654 \\
\hline Between-groups & 102,4167 & 93 & 1,101255 & - \\
\hline Total & 104,2396 & 95 & - & - \\
\hline
\end{tabular}

For level of significance 0,05 and the degrees of freedom $(2,93)$, the value of the critical region is 3,09433 .

As can be seen $0,827654<3,09433$.

Because the test criterion is lower than the critical region and falls within the critical region, hypothesis 2 is accepted. Globality of customers has no significant influence on the importance that companies operating on the market assign to inner innovations.

Verification of Hypothesis 3
Hypothesis $\mathrm{H}_{3}$ : Globality of competition has no significant influence on the importance that companies operating on the market assign to outer innovations.

Alternative Hypothesis $\mathbf{H}_{\underline{A 3}}$ : Globality of competition has significant influence on the importance that companies operating on the market assign to outer innovations.

Table 9 shows responses about importance of outer innovations summarized and divided by globalization of competition. Results for ANOVA can be seen in table 10 .

Table 9: Importance of Outer Innovation Divided by Globalization of Competition

\begin{tabular}{|l|r|r|r|}
\hline Factor & Number of companies & Importance of innovation & Arithmetic mean \\
\hline Region competitors & 32 & 108 & 3,375 \\
\hline National competitors & 33 & 123 & 3,727 \\
\hline Worldwide competitors & 31 & 119 & 3,839 \\
\hline Total & 96 & 350 & 3,646 \\
\hline
\end{tabular}

Table 10: ANOVA Table for Hypothesis 3

\begin{tabular}{|l|r|r|r|c|}
\hline Source of variability & Sum of squares & Degrees of freedom & Mean square & Test criterion \\
\hline Within-group & 3,71933 & 2 & 1,859665 & 1,040363 \\
\hline Between-groups & 166,239 & 93 & 1,787516 & - \\
\hline Total & 169,9583 & 95 & - & - \\
\hline
\end{tabular}

For level of significance 0,05 and the degrees of freedom $(2,93)$, the value of the critical region is 3,09433 .

As can be seen 1,040363<3,09433.

Because the test criterion is lower than the critical region and falls within the critical region, hypothesis 3 is accepted. Globality of competition has no significant influence on the importance that companies operating on the market assign to outer innovations.

\section{Verification of Hypothesis 4}

Hypothesis $\mathrm{H}_{4}$ : Globality of competition has no significant influence on the importance that companies operating on the market assign to inner innovations. 
Alternative Hypothesis $\mathbf{H}_{\mathrm{A4}}$ : Globality of competition has significant influence on the importance that companies operating on the market assign to inner innovations.
Table 11 shows responses about importance of inner innovations summarized and divided by globalization of competition. Results for ANOVA can be seen in table 12 .

Table 11: Importance of Inner Innovation Divided by Globalization of Competition

\begin{tabular}{|l|r|r|r|}
\hline Factor & Number of companies & Importance of innovation & Arithmetic mean \\
\hline Region customers & 32 & 108 & 3,375 \\
\hline National customers & 33 & 117 & 3,545 \\
\hline Worldwide customers & 31 & 94 & 3,032 \\
\hline Total & 96 & 319 & 3,323 \\
\hline
\end{tabular}

Table 12: ANOVA Table for Hypothesis 4

\begin{tabular}{|l|r|r|r|c|}
\hline Source of variability & \multicolumn{1}{|l|}{ Sum of squares } & Degrees of freedom & Mean square & Test criterion \\
\hline Within-group & 4,340023 & 2 & 2,170012 & 2,005086 \\
\hline Between-groups & 100,6496 & 93 & 1,082254 & - \\
\hline Total & 104,9896 & 95 & - & - \\
\hline
\end{tabular}

For level of significance 0,05 and the degrees of freedom $(2,93)$, the value of the critical region is 3,09433 .

As can be seen 2,005086<3,09433.

Because the test criterion is lower than the critical region and falls within the critical region, hypothesis 4 is accepted. Globality of competition has no significant influence on the importance that companies operating on the market assign to inner innovations.

\section{Discussion}

Czech companies apparently assign big importace to both inner and outer innovation. In average, the importance of innovations was rated between three and four points. This opinion is the same in most of the companies, regardless of the global nature of their customers and markets in which they operate. I believe the main reason to the high importance assigned to innovations is the aforementioned changes in the competitive environment, to which the companies either react in time, or start losing their position on the market quickly. It is also possible, that companies which did not put much importance on innovations have been forced to leave the market already. Another possibility, which can lead to this opinion about innovations, can be the fact, that it is a quite modern and often discussed topic. Even companies, which wouldn't have considered these questions before, especially smaller companies, are starting to think about the possibilities of changing their product or the production process. Innovation isn't a mark of a big and wealthy company with enough capital to finance large research.

The only statistically significant difference can be seen between companies with local and national customers - local companies assign less importance to outer innovations. In this case it is very important to realize what companies they are, what product or service they offer. Apparently it is not efficient to try and find a supplier from another region, transport the product or have it sent from far places. The reasons for this may include the existence of an identical product outside the primary region, or the comparison of transport costs to the cost of the product itself. This can be especially local 
consumer goods retail companies (groceries, stationery, drugstores) or providers of services bound to the customer personally (hairdressers, sport centers, restaurants). It is still possible to find potential for innovative thinking in these areas especially in the service area. This potential is very limited in the field of retail, though.

\section{Conclusion}

Only one statistically significant difference has been found - one between the companies with local and national customers. Even this difference isn't very significant, though, and even this group rates the importance of innovations in average at the higher part of the scale. No other differences were proven in the opinion on the importance of innovations among companies with local, national and worldwide customers or local and global competition. This applies to both inner and outer innovations.

This means that the companies in the Czech Republic understand the importance of innovations for their business on the open and globalized market in the Czech economy. This information can be interpreted as good news. The market dynamics cannot be expected to decrease. On the contrary, continued globalization in third world countries, the internet becoming more common, economic growth in developing countries will further escalate the signs of the current changes.

It can be assumed then, that the only successful companies will not only assign big importance to innovations, but will also be able to produce and apply them in time.

\section{Acknowledgements}

This contribution was written within the framework of the IGA (Internal Grant Agency, MSMT) grant-maintained project: Reg. No. IGA/52/FaME/11/A, Applying and usage of employees' education methods with the Knowledge Management elements in the business companies in Czech Republic, and with the financial support of IGA.

\section{References}

Adair, J. E. (2004). 'Efektivníinovace,' 1. vyd. Praha: Alfa, ISBN 80-86851-04-4.

Bartak, J. (2008). 'Od Znalostí k Inovacím: Tvorba, Rozvíjení a Využívání Znalostí v Organizacích,' Prvnívydání.Praha: Alfa, ISBN 978-80-87197-03-5.

Drucker, P. F. \& Medek, P. (1992). Management: Budoucnost Začíná Dnes, 1. vyd. Praha: Management Press, ISBN 80-85603-00-4.

Frankova, E. (2011). 'Kreativitaainovace V Organizaci,' Prvnívydání.Praha: Grada, ISBN 978-80-247-3317-3.

Globální Ekonomický Výhled. ČNB. (2012). 'Českánárodníbanka,' [online]. [cit. 2012-0720].Dostupné http://www.cnb.cz/cs/menova_politika/gev /

Jac, I., Rydvalova, P. a Žizka, M. (2005). 'Inovace v Malém a Středním podnikání,' Vydáníprvní. Brno: Computer Press, ISBN 80251-0853-8.

Kiernan, M. J. \& Skapova, H. (1998). 'Nebo Nepřežiješ: Zásady Strategického Rízení pro 21. století. 1,' vydání. Praha: Management Press, ISBN 80-85943-56-5.

Kosturiak, J. \& Chal', J. (2008). 'Inovace: Vašekonkurenčnívýhoda!,' Vydáníprvní. Brno: Computer Press, ISBN 978-80-251-1929-7.

Kotler, P. \& De bes, F. T. (2005). Inovativní Marketing: Jak Kreativním Myšlenímz Vítězit u Zákazníků, Prvnívydání.Praha: Grada, ISBN 80-247-0921-X.

Porter, M. E. (2004). “Competitive Advantage: Creating and Sustaining Superior Performance," New York: Free Press, Free Press Export Edition. ISBN 0-7432-6087-2.

Robins, S. P. \& Coulter, M. (2004). 'Management, Sedmé Vydání,' Praha: Grada, ISBN 80-247-0495-1. 
11 Journal of Innovation \& Business Best Practice

Roffe, I. (1999). "Innovation and Creativity in Organisations: A Review of the Implications for Training and Development," Journal of European Industrial Training, vol. 23, no. 4/5, p. 224-241.

Souder, W. E. \& Sherman, J. D. (1994). 'Managing New Technology Development,' New York: McGraw-Hill.

Thompson, A. A. \& Strickland, A. J. (2001). 'Strategic Management: Concepts and Cases,' Twelfth Edition. New York: McGrawHill/Irwin, ISBN 0-07-231499-0.

Tidd, J. (2001). 'From Knowledge Management to Strategic Competence: Measuring Technological, Market and Organizational Innovation,' London: Imperial College Press.

Tidd, J., Bessant, J. R. \& Pavitt, K. (2007). 'Řízení Inovací,' 3rd edition. Brno: Computer Press, ISBN 978-80-251-1466-7.

Tomek, G. a Vavrova, V. (2009). 'Jak Zvýšit Konkurenceschopnost Firmy,' 1. vydání. Praha: C. H. Beck, ISBN 978-80-7400-098-0. 